\title{
Safe use of radiopharmaceuticals in patients with chronic kidney disease: a systematic review
}

\author{
Nanno Schreuder ${ }^{1,2^{*}}$ (D) Iris de Romijn ${ }^{3}$, Pieter L. Jager ${ }^{4}$, Jos G. W. Kosterink ${ }^{1,5}$ and Eugène P. van Puijenbroek ${ }^{1,6}$
}

\author{
${ }^{*}$ Correspondence: \\ n.schreuder@rug.nl \\ ${ }^{1}$ Groningen Research \\ Institute of Pharmacy, \\ Unit of PharmacoTherapy, \\ Epidemiology \\ and Economics, University \\ of Groningen, Groningen, \\ The Netherlands \\ Full list of author information \\ is available at the end of the \\ article
}

\begin{abstract}
Background: Patients with chronic kidney disease (CKD) may need to have their radiopharmaceutical dosage adjusted to prevent adverse effects and poor outcomes, but there are few recommendations on radiopharmaceutical dosing for this group of patients. The aim of this study is to provide an overview of the available information on radiopharmaceutical dose recommendations for patients with CKD.
\end{abstract}

Methods: We performed a systematic literature review according to the Preferred Reporting Items for Systematic Reviews and Meta-Analyses (PRISMA) statement. We conducted a literature search in the MEDLINE (PubMed) and Embase databases and screened potentially relevant studies using inclusion and exclusion criteria. We independently assessed the included observational studies' methodologies and extracted relevant data.

Results: Of the 5795 studies first identified, 34 were included in this systematic review. These studies described three radiopharmaceuticals: $\left[{ }^{[31} 1\right]$ sodium iodine, $\left[{ }^{18} \mathrm{~F}\right]$ fludeoxyglucose, and $\left[{ }^{[31}\right]$ iobenguane. Twenty-nine studies (85.3\%) reported data on patients with CKD stage 5, while only three studies mentioned CKD patients in other stages (8.8\%).

Conclusion: We found no consistent recommendations for radiopharmaceutical dosing in patients with CKD. Although some studies do mention dosing difficulties in patients with CKD, information is available for only a few radiopharmaceuticals, and recommendations are sometimes contradictory. Further research on radiopharmaceutical dosing in patients with CKD is needed to determine whether these patients require specific dosing, especially for therapeutic radiopharmaceuticals where a non-optimised dose may lead to an increased risk of toxicity for non-targeted organs. Including patients with CKD in studies and providing specific information about dosing in these patients should be a priority for the radiopharmaceutical community.

Keywords: Radiopharmaceuticals, Nuclear medicine, Chronic kidney disease, Renal insufficiency, Drug dosage calculations, Drug safety

\section{Introduction}

Nuclear medicine plays an important role in the diagnosis and therapy of diseases, particularly in the field of oncology. The field of nuclear medicine relies on radioactive compounds, so-called radiopharmaceuticals (Smith et al. 2012). Selecting the right dose of a radiopharmaceutical, expressed in becquerels $(\mathrm{Bq})$ as the activity of the compound's author(s) and the source, provide a link to the Creative Commons licence, and indicate if changes were made. The images or other third party material in this article are included in the article's Creative Commons licence, unless indicated otherwise in a credit line to the material. If material is not included in the article's Creative Commons licence and your intended use is not permitted by statutory regulation or exceeds the permitted use, you will need to obtain permission directly from the copyright holder. To view a copy of this licence, visit http:// creativecommons.org/licenses/by/4.0/. 
radionuclide, is of high importance. For diagnostic radiopharmaceuticals, the ideal dose will provide accurate, useful diagnostic information while keeping the radiation dose to the patient low (Pickett and Theobald 2011; Fahey and Stabin 2014). The efficacy will depend on the biodistribution of the diagnostic radiopharmaceutical. Important aspects include localisation in a target organ, localisation in non-target organs, and the mechanisms-such as biological excretion-for removing non-target radioactivity. Advantageous biodistribution will contribute to a good target-to-non-target activity ratio, ensuring optimal image quality which allows a clear diagnostic outcome (Pickett and Theobald 2011). For therapeutic radiopharmaceuticals, the ideal dose will deliver the right therapeutic activity without causing adverse effects and with a minimum radiation dose to non-target organs or tissues (Chan et al. 2011; Kassis and Adelstein 2005; Meredith and Wessels 2008). The biodistribution of the therapeutic radiopharmaceutical is important because localisation in the target organ will determine the therapeutic response, and non-target organs are at risk of toxicity (Pickett and Theobald 2011).

Chronic kidney disease (CKD), a growing health problem with an estimated prevalence of $11-13 \%$ in the general population, is characterised by kidney function decline. It can result from diseases, such as diabetes mellitus and hypertension, or from aging (Hill et al. 2016; Girndt et al. 2016; Nissenson et al. 2001). CKD may reduce the excretion rate of pharmaceuticals and their metabolites, elevating plasma concentrations and requiring the dose to be adjusted (Matzke and Frye 1997; Dreisbach and Lertora 2008). Similarly, for radiopharmaceuticals that are cleared by the kidneys, the biodistribution of the radioactive drug is likely to be altered in patients with CKD. For diagnostic radiopharmaceuticals, decreased clearance may lead to prolonged blood pool activity and subsequently to a poor target-to-non-target ratio, which may decrease image quality and ultimately affect the diagnostic outcome. For therapeutic radiopharmaceuticals, decreased clearance may lead to increased activity at the target organs or non-target organs, which increases the risk of toxicity. Therefore, it is expected that the radiopharmaceutical dosage in patients with CKD will have to be adjusted (Krens et al. 2019; Munar and Singh 2007).

At present, the dose of a radiopharmaceutical is fixed in most cases, although it is sometimes adjusted for body weight, as in the case of children and obese patients (Sjögreen Gleisner et al. 2017; Lassmann and Treves 2014). However, standards for radiopharmaceutical dosing in patients with CKD are lacking. One review describes treatment with radioiodine for hyperthyroidism and thyroid cancer in end-stage CKD. The review mentions that the available literature is scarce and that standards, based only on analysis of single case reports, are not coherent (Saracyn et al. 2014). Some available nuclear medicine guidelines contain only one paragraph on the use of radiopharmaceuticals in patients with CKD. Only one nuclear medicine guideline gives a specific dose recommendation for these patients, advising that the administered dose of bone-seeking therapeutic radiopharmaceuticals for palliation of bone pain should be lowered by $50 \%$ in patients with creatinine clearance of less than $50 \mathrm{~mL} / \mathrm{min}$ (Bodei et al. 2008a). Other guidelines provide only general, nonspecific comments, such as recommending that renal function should be assessed, that a nephrologist should be consulted, that the administration of the radiopharmaceutical should be carefully planned and managed, or even that patients with CKD should be excluded (Bodei et al. 2008a; Poeppel et al. 
2018; Wyngaert et al. 2016; Bombardieri et al. 2010; Silberstein et al. 2012; Zaknun et al. 2013; Hope et al. 2019; Luster et al. 2008). While these effects are particularly relevant in therapeutic applications because a change in biodistribution may affect therapy outcomes or increase the risk of toxicity in these patients, diagnostic radiopharmaceutical guidelines also indicate that scans obtained in CKD patients may be suboptimal due to a change in biodistribution. Some suggest increasing the time between administration of the radiopharmaceutical and imaging (Wyngaert et al. 2016; Boellaard et al. 2015; Bartel et al. 2018; Dam et al. 2014; Practice Guideline 2009). However, several guidelines for both therapeutic and diagnostic radiopharmaceuticals mention that while dose adjustment may be needed in this group of patients, little is known about this topic (Poeppel et al. 2018; Bombardieri et al. 2010; Zaknun et al. 2013; Silberstein et al. 2003; Balon et al. 2011; Djang et al. 2012).

Therefore, our aim in this systematic review is to provide an overview of the available information on radiopharmaceutical dose recommendations for patients with CKD.

\section{Methods}

\section{Study design}

We conducted this systematic literature review according to the Preferred Reporting Items for Systematic Reviews and Meta-Analyses (PRISMA) statement (Moher et al. 2009), and the review was registered in the International Prospective Register of Systematic Reviews (PROSPERO) under number CRD42019136107 (Centre for Reviews and Dissemination 2019).

\section{Search strategy}

We performed a computerised literature search using the databases MEDLINE (PubMed) and Embase. Two researchers (I.d.R. and N.S.) developed a search string for each database (Table 1) using keywords for both CKD and radiopharmaceuticals. No publication year limits were applied. Only studies in the English language were included, and a filter was applied to exclude animal-only studies. An additional filter was applied in Embase to exclude studies available in MEDLINE. We screened the selected studies and review articles to identify additional relevant studies and references. The initial search was completed on 10 May 2019 and updated with recent articles until 7 October 2020.

\section{Study selection}

All titles and abstracts were screened, and we retrieved the full text of potentially relevant studies. Two researchers (I.d.R. and N.S.) independently assessed the full text of each study for relevance. We included studies that met the following inclusion criteria: They described patients diagnosed or treated with a radiopharmaceutical and who suffered from CKD, they used a radiopharmaceutical that is (at least partly) cleared renally, and they made recommendations for an adequate dose in these patients or gave additional advice. Studies were excluded if they gave no relevant information on dosing or aspects related to dosing, addressed only the radiation safety of staff, described renal imaging, or were review articles. 
Table 1 Search strategies employed for PubMed and Embase

\begin{tabular}{|c|c|}
\hline Database & Search string \\
\hline PubMed & $\begin{array}{l}\text { (((((Radiopharmaceuticals(MeSH) } \\
\text { OR radiopharmaceutical*(tiab) } \\
\text { OR radioactive drug*(tiab) } \\
\text { OR radioiodine(tiab)))) AND } \\
\text { ((Kidney Diseases(MeSH) OR } \\
\text { kidney disease*(tiab) OR Renal } \\
\text { Insufficiency(MeSH) OR renal } \\
\text { insufficien*(tiab) OR renal } \\
\text { impairment(tiab) OR Glo- } \\
\text { merular Filtration Rate(Mesh) } \\
\text { OR glomerular filtration } \\
\text { rate*(tiab) OR eGFR(tiab) OR } \\
\text { Metabolic Clearance Rate(MeSH) } \\
\text { OR renal clearance(tiab)))) } \\
\text { NOT ("Animals"(Mesh) NOT } \\
\text { "Humans"(Mesh))) AND } \\
\text { English(Language) }\end{array}$ \\
\hline Embase & $\begin{array}{l}\text { ('radiopharmaceutical agent'/exp OR } \\
\text { 'radiopharmaceutical agent':ti,ab) } \\
\text { AND ('kidney disease'/exp OR 'kid- } \\
\text { ney disease':ti,ab OR 'kidney failure'/ } \\
\text { exp OR 'kidney failure':ti,ab OR 'renal } \\
\text { impairment':ti,ab OR 'glomerulus } \\
\text { filtration rate'/exp OR 'glomerular } \\
\text { filtration rate':ti,ab OR 'estimated } \\
\text { glomerular filtration rate':ti,ab OR } \\
\text { 'metabolic clearance'/exp OR 'renal } \\
\text { clearance':ti,ab) NOT ('animal'/exp } \\
\text { NOT 'human'/exp) AND (eng- } \\
\text { lish)/lim AND (embase)/lim NOT } \\
\text { ((embase)/lim AND (medline)/lim) }\end{array}$ \\
\hline
\end{tabular}

\section{Assessment of methodological quality}

Two researchers (I.d.R. and N.S.) independently assessed the methodological quality of the included observational studies using the Newcastle-Ottawa Scale (NOS): Quality Assessment Form for Cohort and Case-Control Studies (Ottawa Hospital Research Institute 2019). For each study, we scored nine items in three domains: selection, comparability, and exposure or outcome. Scores were added to create an aggregate score. The NOS scores were converted to ratings of 'good,' 'fair', or 'poor' according to Agency for Healthcare Research and Quality standards (Singh et al. 2015). Studies of good quality were defined as those awarded 3-4 stars in the selection domain and 1-2 stars in the comparability domain and 2 stars in the exposure or outcome domain. Fair studies were defined as those awarded 2 stars in the selection domain and 1-2 stars in the comparability domain and 1-2 stars in the exposure or outcome domain. Poor-quality studies were defined as those awarded $0-1$ stars in the selection domain or 0 in the comparability domain or 0 in the exposure or outcome domain. Where opinions on a score differed, we consulted a third reviewer (E.v.P.) to reach consensus.

\section{Data collection}

For studies meeting the selection criteria, we extracted data using a standardised approach. Two researchers (I.d.R. and N.S.) independently extracted the following 
data: (1) author and journal, (2) year of publication, (3) study design, (4) name(s) of radiopharmaceutical(s) and the administered dose(s), (5) indication, (6) number of patients with CKD, (7) stage of CKD, (8) where applicable, the type and timing of dialysis after administration of the radiopharmaceutical, (9) recommendation(s) for adjustment of dose, (10) other advice on aspects such as adjustment of dialysis or scintigraphy, (11) reasons for dose adjustment, and (12) study limitations. We standardised the radiopharmaceuticals' names according to the Anatomical Therapeutic Chemical classification system (WHO Collaborating Centre 2019), and the International Consensus Radiochemistry Nomenclature Guidelines (Coenen et al. 2019). Where studies reported the administered dose using the unit curie $(\mathrm{Ci})$, we converted this to the SI derived unit becquerel $(\mathrm{Bq})$ for uniformity of outcome (Allisy 1995). Patients with CKD were classified using the terminology of the CKD standard (Table 2), which includes five stages of kidney damage, from kidney damage with normal kidney function in stage 1 to kidney failure in stage 5 (National Kidney Foundation, Inc 2019; International Society of Nephrology 2013). We classified patients on dialysis as stage 5 if they had not been assigned to a specific stage in a study. When the extracted data were not in agreement and consensus could not be reached between the two researchers, a third researcher (E.v.P.) was consulted to resolve discrepancies.

\section{Results}

\section{Search results}

The literature search identified a total of 5795 studies in PubMed $(n=2,684)$ and Embase $(n=3111)$; another 11 studies were identified from references. After removing duplicates $(n=81)$, we screened 5725 studies by title (and abstract, where necessary), resulting in 65 potentially relevant studies. After a full-text screening we excluded another 31 studies for various reasons: they gave no relevant information on dosing or aspects related to dosing $(n=18)$, they addressed only the radiation safety of staff $(n=5)$, described renal imaging $(n=5)$, or were review $(n=3)$. A total of 34 studies remained for inclusion in this systematic review (Akers et al. 2016; Aktaş et al. 2008; Alevizaki et al. 2006; Bhat et al. 2017; Courbon et al. 1997,2006; Culpepper et al. 1992; Daumerie et al. 1996; Demko et al. 1998; Driedger et al. 2006; El-Zeftawy et al. 2017; Fofi et al. 2013; Holst et al. 2005; Howard and Glasser 1981; Jiménez et al. 2001; Kaptein et al. 2000; Kode et al. 2017; Laffon et al. 2008; Magné et al. 2002; McKay and Malaroda 2019; McKillop et al. 1985; Mello et al. 1994; Minamimoto et al. 2007; Miyasaka et al. 1997; Morrish et al. 1990; Pahlka and Sonnad 2006; Sinsakul and Ali

Table 2 Classification of CKD by GFR (International Society of Nephrology2013; National Kidney Foundation, Inc 2019)

\begin{tabular}{|c|c|c|}
\hline Stage & Description & $\mathrm{GFR}, \mathrm{mL} / \mathrm{min} / 1.73 \mathrm{~m}^{2}$ \\
\hline 1 & Kidney damage with normal or increased GFR & $\geq 90$ \\
\hline 2 & Kidney damage with mild decreased GFR & $60-89$ \\
\hline 3 & Moderately decreased GFR & $30-59$ \\
\hline 4 & Severely decreased GFR & $15-29$ \\
\hline 5 & Kidney failure & $<15$ (or dialysis) \\
\hline
\end{tabular}

Abbreviations: CKD, chronic kidney disease; GFR, glomerular filtration rate 
2004; Tobes et al. 1989; Toriihara et al. 2015; Toubert et al. 2001; Vermandel et al. 2020; Wang et al. 2003; Willegaignon et al. 2010; Yeyin et al. 2016). The selection process is illustrated in a PRISMA flow diagram (Fig. 1).

The 34 selected studies included 12 case reports (35.3\%), 11 case series (32.4\%), five case-control studies (14.7\%), two cohort studies (5.9\%), three theoretical models $(8.8 \%)$, and one case report with a theoretical model $(2.9 \%)$. The radiopharmaceuticals reported in these studies are $\left[{ }^{18} \mathrm{~F}\right]$ fludeoxyglucose (FDG) $(n=5 ; 14.7 \%),\left[{ }^{131} \mathrm{I}\right]$ sodium iodine $(n=28 ; 82.4 \%)$, and $\left[{ }^{131} \mathrm{I}\right]$ iobenguane $(n=1 ; 2.9 \%)$. Twenty-nine studies reported data for patients with CKD stage 5 (85.3\%), while three studies included patients in other stages $(8.8 \%)$. In two studies, the CKD stage was not identified, or it was determined in a non-standard fashion (5.9\%). Patients in the 29 studies reporting data for CKD stage 5 were on renal replacement therapy. Nineteen studies described patients on haemodialysis (HD) (65.5\%), four studies described patients on continuous ambulatory peritoneal dialysis (CAPD) (13.8\%), three studies described patients on HD or CAPD (10.3\%), one study described patients on HD or intermittent peritoneal dialysis (IPD) (3.4\%), one study described patients on continuous haemodialysis (3.4\%), and one study did not specify the type of dialysis (3.4\%). In these studies, the timing of dialysis varied. For HD, the start of dialysis varied from 15 to $72 \mathrm{~h}$ after administration of the radiopharmaceutical, the number of dialyses varied from one to five times, and the timing intervals varied. For CAPD, the fluid changes varied from four to eight times a day. An overview of the included studies' characteristics is presented in Table 3.

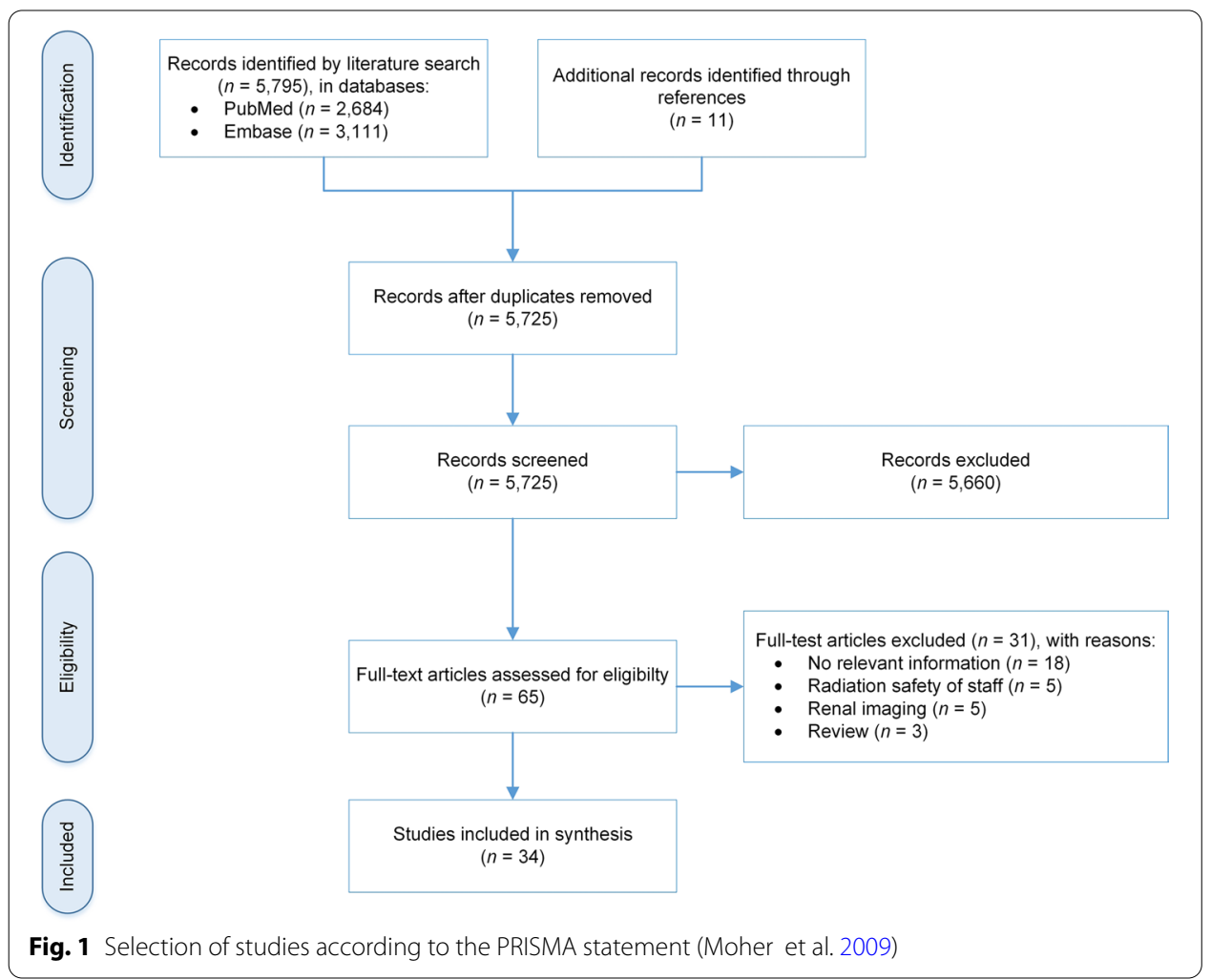


Table 3 Overview of included studies with their characteristics

\begin{tabular}{|c|c|c|c|c|c|c|c|c|c|}
\hline References & Year & $\begin{array}{l}\text { Study } \\
\text { design }\end{array}$ & $\begin{array}{l}\text { Number } \\
\text { of } \\
\text { patients }\end{array}$ & Radiopharmaceutical & Indication & $\begin{array}{l}\text { Dose } \\
\text { (MBq) }\end{array}$ & $\begin{array}{l}\text { Stage of } \\
\text { kidney } \\
\text { failure } \\
\text { (CKD) }\end{array}$ & $\begin{array}{l}\text { f Type of } \\
\text { dialysis } \\
\text { (number } \\
\text { of } \\
\text { patients) }\end{array}$ & $\begin{array}{l}\text { Timing of dialysis } \\
\text { after administration } \\
\text { r radiopharmaceutical } \\
\text { ) }\end{array}$ \\
\hline $\begin{array}{l}\text { Akers et al. } \\
\text { (2016) }\end{array}$ & 2016 & $5 \cos$ & 58 & {$\left[{ }^{18} \mathrm{~F}\right]$ fludeoxyglucose } & $\mathrm{PET} / \mathrm{CT}$ & $\begin{array}{r}370- \\
555\end{array}$ & $1-5$ & NA & NA \\
\hline $\begin{array}{l}\text { Aktaş et al. } \\
\text { (2008) }\end{array}$ & 2008 & 3 CCS & 10 & {$\left[{ }^{131} \mid\right]$ sodium iodine } & $\mathrm{TC}$ & $\begin{array}{l}1110- \\
3700\end{array}$ & 5 & $\begin{array}{l}\text { HD (6); } \\
\text { CAPD } \\
\text { (4) }\end{array}$ & $\begin{array}{l}24 \text { h continued every } \\
\text { day for } 5 \text { d; CAPD } \\
\text { increased from } 4 \text { to } \\
6-8 \text { times a day }\end{array}$ \\
\hline $\begin{array}{l}\text { Alevizaki } \\
\text { et al. } \\
(2006)\end{array}$ & 2006 & $5 \mathrm{CS}$ & 5 & {$\left[{ }^{131} 1\right]$ sodium iodine } & PTC & $\begin{array}{l}1110- \\
2590\end{array}$ & 5 & $\begin{array}{l}\mathrm{HD}(4) \\
\text { IPD } \\
(1)\end{array}$ & $\begin{array}{l}48 \mathrm{~h} \text {, and } 2 \text { patients } \\
\text { also } 96 \mathrm{~h}\end{array}$ \\
\hline $\begin{array}{l}\text { Bhat et al. } \\
\text { (2017) }\end{array}$ & 2017 & $\mathrm{CR}$ & 1 & {$\left[{ }^{131} \mid\right]$ sodium iodine } & PTC & 1850 & 5 & $\mathrm{HD}$ & $15 \mathrm{~h}, 27 \mathrm{~h}, 43 \mathrm{~h}$ \\
\hline $\begin{array}{l}\text { Courbon } \\
\text { et al. } \\
\text { (1997) }\end{array}$ & 1997 & CR & 1 & {$\left[{ }^{131} 1\right]$ sodium iodine } & TC & 3700 & 5 & $\mathrm{HD}$ & $2 \mathrm{~d}, 4 \mathrm{~d}$ \\
\hline $\begin{array}{l}\text { Courbon } \\
\text { et al. } \\
(2006)\end{array}$ & 2006 & & 2 & {$\left[{ }^{131} \mid\right]$ sodium iodine } & TC & 3700 & 5 & $\mathrm{HD}$ & 72 h, 122 h-144 h \\
\hline $\begin{array}{l}\text { Culpepper } \\
\text { et al. } \\
\text { (1992) }\end{array}$ & 1992 & $2 \mathrm{CR}$ & 1 & {$\left[{ }^{131} 1\right]$ sodium iodine } & FTC & 4773 & 5 & $\mathrm{HD}$ & $24 h, 43 h, 66 h$ \\
\hline $\begin{array}{l}\text { Daumerie } \\
\text { et al. } \\
\text { (1996) }\end{array}$ & 1996 & $5 \mathrm{CS}$ & 3 & {$\left[{ }^{131} \mid\right]$ sodium iodine } & PTC & $\begin{array}{l}2 \text { treat- } \\
\text { ments } \\
\text { of } 925\end{array}$ & 5 & $\mathrm{HD}$ & $2 d, 3 d$ \\
\hline $\begin{array}{l}\text { Demko } \\
\text { et al. } \\
\text { (1998) }\end{array}$ & 1998 & $3 C R$ & 1 & {$\left[{ }^{131} \mid\right]$ sodium iodine } & TMNG & 1045.62 & 5 & $\mathrm{HD}$ & $24 \mathrm{~h}$ \\
\hline $\begin{array}{l}\text { Driedger } \\
\text { et al. } \\
\text { (2006) }\end{array}$ & 2006 & $5 \mathrm{CS}$ & 3 & {$\left[{ }^{131} \mid\right]$ sodium iodine } & PTC & $\begin{array}{l}3700 \\
3700 \\
2500\end{array}$ & 5 & $\begin{array}{l}\mathrm{HD}(2) ; \\
\text { CAPD } \\
(1)\end{array}$ & NA \\
\hline $\begin{array}{l}\text { El-Zeftawy } \\
\text { et al. } \\
\text { (2017) }\end{array}$ & 2017 & $7 \mathrm{CCS}$ & 27 & {$\left[{ }^{131} \mid\right]$ sodium iodine } & DTC & $\begin{array}{l}\text { Mean } \\
\text { dose } \\
5550\end{array}$ & 3 and 4 & NA & NA \\
\hline $\begin{array}{l}\text { Fofi et al. } \\
\text { (2013) }\end{array}$ & 2013 & $3 \mathrm{CS}$ & 2 & {$\left[{ }^{131} 1\right]$ sodium iodine } & PTC & 1850 & 5 & $\mathrm{CHD}$ & $24 \mathrm{~h}, 48 \mathrm{~h}$ \\
\hline $\begin{array}{l}\text { Holst et al. } \\
\text { (2005) }\end{array}$ & 2005 & $\begin{array}{c}\text { CR and } \\
\text { TM }\end{array}$ & 1 & {$\left[{ }^{131} 1\right]$ sodium iodine } & PTC $^{\mathrm{a}}$ & 3637 & 5 & $\mathrm{HD}$ & $2 d, 3 d, 4 d$ \\
\hline $\begin{array}{l}\text { Howard } \\
\text { and } \\
\text { Glasser } \\
\text { (1981) }\end{array}$ & 1981 & $C R$ & 1 & {$\left[{ }^{131} \mid\right]$ sodium iodine } & PTC & 740 & 5 & $\mathrm{HD}$ & NA \\
\hline $\begin{array}{l}\text { Jiménez } \\
\text { et al. } \\
\text { (2001) }\end{array}$ & 2001 & CS & 3 & {$\left[{ }^{[31} 1\right]$ sodium iodine } & PTC & $\begin{array}{l}2775 \\
3219 \\
4440\end{array}$ & 5 & $\mathrm{HD}$ & $\begin{array}{l}24 \mathrm{~h}, 48 \mathrm{~h}, 72 \mathrm{~h}, 96 \mathrm{~h}, \\
144 \mathrm{~h}\end{array}$ \\
\hline $\begin{array}{l}\text { Kaptein } \\
\text { et al. } \\
(2000)\end{array}$ & 2000 & CS & 2 & {$\left[{ }^{131} 1\right]$ sodium iodine } & PTC & $\begin{array}{l}980 \\
\quad 1110\end{array}$ & 5 & CAPD & $3-5$ times a day \\
\hline $\begin{array}{l}\text { Kode et al. } \\
\text { (2017) }\end{array}$ & 2017 & CCS & 30 & {$\left[{ }^{18} \mathrm{~F}\right]$ fludeoxyglucose } & $\mathrm{PET} / \mathrm{CT}$ & $\begin{array}{c}5.18 / \\
\mathrm{kg}\end{array}$ & 4 and 5 & $N A^{b}$ & NA \\
\hline $\begin{array}{l}\text { Laffon et al. } \\
\text { (2008) }\end{array}$ & 2008 & $3 \mathrm{TM}$ & NA & {$\left[{ }^{18} \mathrm{~F}\right]$ fludeoxyglucose } & NA & NA & NA & NA & NA \\
\hline $\begin{array}{l}\text { Magné } \\
\text { et al. } \\
\text { (2002) }\end{array}$ & 2002 & $2 C R$ & 1 & {$\left[{ }^{131} 1\right]$ sodium iodine } & PTC & 1850 & 5 & $\mathrm{HD}$ & $24 \mathrm{~h}, 72 \mathrm{~h}, 144 \mathrm{~h}$ \\
\hline $\begin{array}{l}\text { McKay and } \\
\text { Malaroda } \\
\text { (2019) }\end{array}$ & 2019 & $9 \mathrm{TM}$ & NA & {$\left[{ }^{131} 1\right]$ sodium iodine ${ }^{c}$} & TD & NA & 5 & NA & $\begin{array}{l}\text { Several timing inter- } \\
\text { vals were simulated }\end{array}$ \\
\hline $\begin{array}{l}\text { McKillop } \\
\text { et al. } \\
\text { (1985) }\end{array}$ & 1985 & $5 C R$ & 1 & {$\left[{ }^{131} \mid\right]$ sodium iodine } & $\mathrm{GD}$ & 462.5 & 5 & $\mathrm{HD}$ & $3 d$ \\
\hline
\end{tabular}


Table 3 (continued)

\begin{tabular}{|c|c|c|c|c|c|c|c|c|c|}
\hline References & Year & $\begin{array}{l}\text { Study } \\
\text { design }\end{array}$ & $\begin{array}{l}\text { Number } \\
\text { of } \\
\text { patients }\end{array}$ & Radiopharmaceutical & Indication & $\begin{array}{l}\text { Dose } \\
\text { (MBq) }\end{array}$ & $\begin{array}{l}\text { Stage of } \\
\text { kidney } \\
\text { failure } \\
\text { (CKD) }\end{array}$ & $\begin{array}{l}\text { Type of } \\
\text { dialysis } \\
\text { (number } \\
\text { of } \\
\text { patients) }\end{array}$ & $\begin{array}{l}\text { Timing of dialysis } \\
\text { after administration } \\
\text { radiopharmaceutical }\end{array}$ \\
\hline $\begin{array}{l}\text { Mello et al. } \\
\text { (1994) }\end{array}$ & 1994 & & 1 & {$\left[{ }^{131} \mid\right]$ sodium iodine } & PTC & $\begin{array}{l}2 \text { treat- } \\
\text { ments } \\
\text { of } 3700\end{array}$ & 5 & $\mathrm{HD}$ & $41 \mathrm{~h}, 89 \mathrm{~h}$ \\
\hline $\begin{array}{l}\text { Minami- } \\
\text { moto } \\
\text { et al. } \\
(2007)\end{array}$ & 2007 & $\cos$ & 20 & {$\left[{ }^{18} \mathrm{~F}\right]$ fludeoxyglucose } & $\mathrm{PET} / \mathrm{CT}$ & $\begin{array}{l}210- \\
360\end{array}$ & $N A^{d}$ & NA & NA \\
\hline $\begin{array}{l}\text { Miyasaka } \\
\text { et al. } \\
\text { (1997) }\end{array}$ & 1997 & & 1 & {$\left[{ }^{131} \mid\right]$ sodium iodine } & GD & 740 & 5 & $\mathrm{HD}$ & $24 \mathrm{~h}$ \\
\hline $\begin{array}{l}\text { Morrish } \\
\text { et al. } \\
\text { (1990) }\end{array}$ & 1990 & $C R$ & 1 & {$\left[{ }^{131} \mid\right]$ sodium iodine } & PTC & $\begin{array}{l}1850 ; \\
4440 ; \\
5550 ; \\
9250\end{array}$ & 5 & $\mathrm{HD}$ & $48 \mathrm{~h}, 96 \mathrm{~h}, 144 \mathrm{~h}$ \\
\hline $\begin{array}{l}\text { Pahlka and } \\
\text { Sonnad } \\
\text { (2006) }\end{array}$ & 2006 & $5 \mathrm{TM}$ & NA & {$\left[{ }^{131} \mid\right]$ sodium iodine } & TC & NA & 5 & $\begin{array}{l}\text { HD; } \\
\text { CAPD }\end{array}$ & $\begin{array}{l}\text { Several timing inter- } \\
\text { vals were simulated }\end{array}$ \\
\hline $\begin{array}{l}\text { Sinsakul } \\
\text { and Ali } \\
(2004)\end{array}$ & 2004 & & 2 & {$\left[{ }^{131} \mid\right]$ sodium iodine } & PTC & $\begin{array}{l}3700 ; \\
5809\end{array}$ & 5 & $\mathrm{HD}$ & $20 h-24 h$ \\
\hline $\begin{array}{l}\text { Tobes et al. } \\
(1989)^{e}\end{array}$ & 1989 & CCS & 1 & {$\left[{ }^{131} \mid\right]$ iobenguane } & PC & 18.5 & 5 & $H D$ & NA \\
\hline $\begin{array}{l}\text { Toriihara } \\
\text { et al. } \\
\text { (2015) }\end{array}$ & 2015 & CCS & 24 & {$\left[{ }^{18}\right.$ F]fludeoxyglucose } & $\mathrm{PET} / \mathrm{CT}$ & $3.7 / \mathrm{kg}$ & 5 & $\mathrm{HD}$ & NA \\
\hline $\begin{array}{l}\text { Toubert } \\
\text { et al. } \\
\text { (2001) }\end{array}$ & 2001 & $C R$ & 1 & {$\left[{ }^{131} \mid\right]$ sodium iodine } & FTC & 814 & 5 & CAPD & 4 times a day \\
\hline $\begin{array}{l}\text { Vermandel } \\
\text { et al. } \\
\text { (2020) }\end{array}$ & 2020 & CS & 6 & {$\left[{ }^{131} \mid\right]$ sodium iodine } & TC & $\begin{array}{l}1842- \\
3747\end{array}$ & 5 & $H D$ & $42 \mathrm{~h}, 90 \mathrm{~h}$ \\
\hline $\begin{array}{l}\text { Wang et al. } \\
\text { (2003) }\end{array}$ & 2003 & & 2 & {$\left[{ }^{131} \mid\right]$ sodium iodine } & PTC & $\begin{array}{c}3700 \\
5550\end{array}$ & 5 & CAPD & 4 times a day \\
\hline $\begin{array}{l}\text { Wille- } \\
\text { gaignon } \\
\text { et al. } \\
\text { (2010) }\end{array}$ & 2010 & & 1 & {$\left[{ }^{131} \mid\right]$ sodium iodine } & DTC & 3700 & 5 & CAPD & NA \\
\hline $\begin{array}{l}\text { Yeyin et al. } \\
\text { (2016) }\end{array}$ & 2016 & & 3 & {$\left[{ }^{[31} \mid\right]$ sodium iodine } & DTC & $\begin{array}{l}2775 \\
\text { and } \\
1850 ; \\
2775 ; \\
1850\end{array}$ & 5 & $\mathrm{HD}$ & $24 h, 48 h$ \\
\hline
\end{tabular}

CAPD, continuous ambulatory peritoneal dialysis; CCS, case-control study; CHD, continuous haemodialysis; CKD, chronic kidney diseases; COS, cohort study; CR, case report; CS, case series; DTC, differentiated thyroid cancer; FTC, follicular thyroid cancer; GD, Graves' disease; HD, haemodialysis; IPD, intermittent peritoneal dialysis; NA, not available; PC, pheochromocytoma; $\mathrm{PET} / \mathrm{CT}$, positron emission tomography/computed tomography; PTC, papillary thyroid cancer; TC, thyroid cancer; TD, thyroid disease; TM, Theoretical model; TMNG, toxic multinodular goiter

${ }^{a}$ Although the study describes hyperthyroidism as well, the reported case was treated with [ $\left[{ }^{131} 1\right]$ sodium iodine for thyroid cancer

${ }^{\mathrm{b}} 12$ patients were on dialysis, type and timing were not specified

${ }^{C}$ In this study a pharmacokinetic software model was developed and validated with data of ${ }^{131}{ }^{1},{ }^{123}$ and ${ }^{124}$ I

${ }^{\mathrm{d}}$ Patients with a blood serum creatinine level $>1.1 \mathrm{mg} / \mathrm{dl}$

${ }^{\mathrm{e}}$ The findings in one patient were compared with two patients with mild to moderate renal function 


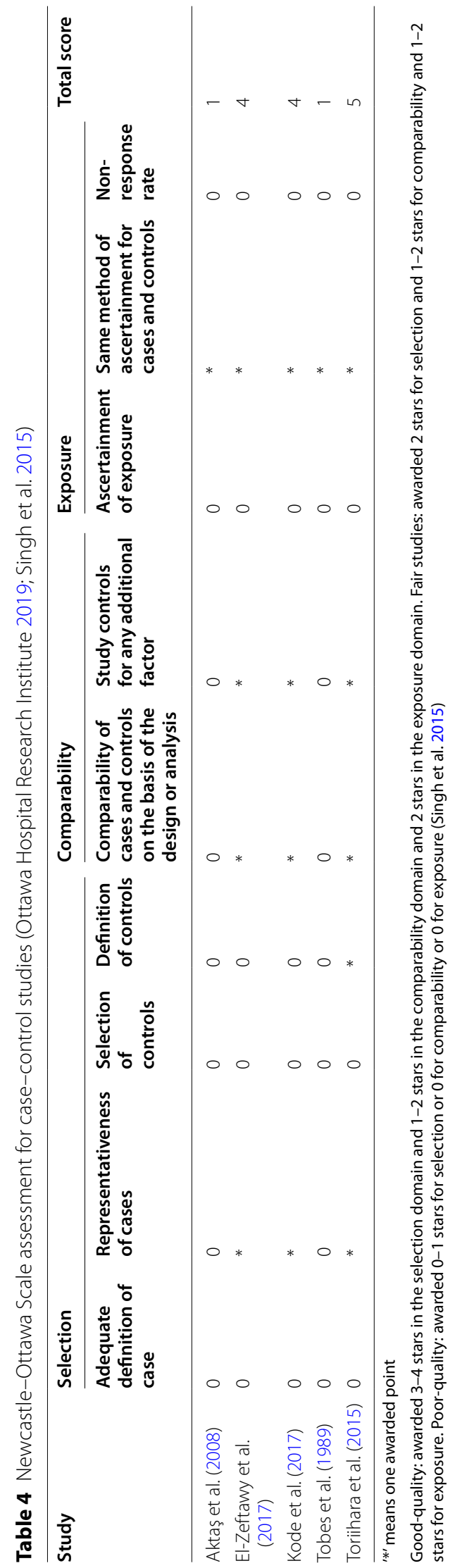




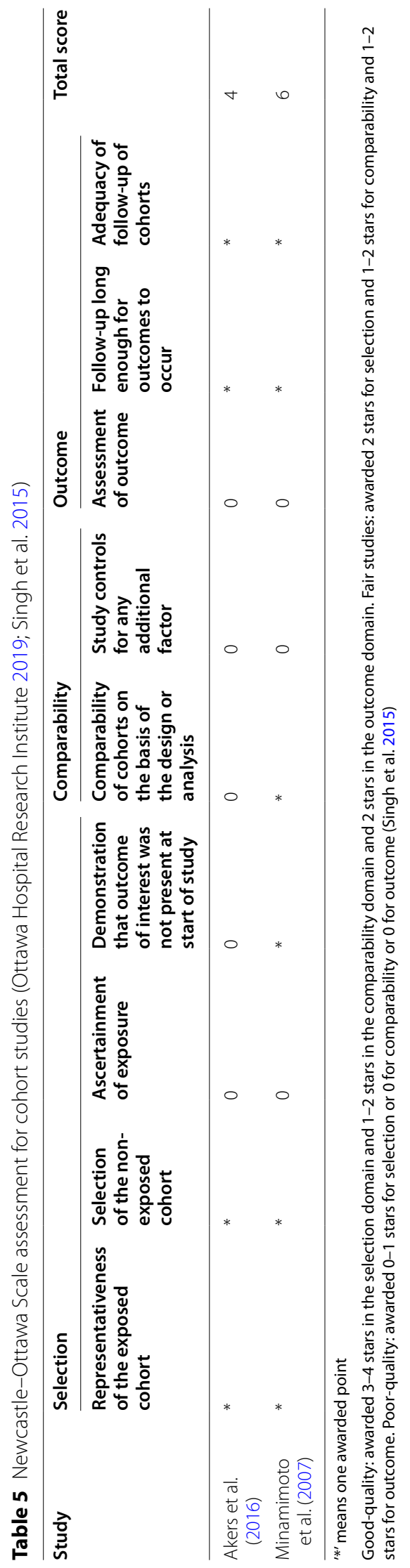


Table 6 Overview of dose recommendations and other advice for diagnostic radiopharmaceuticals

\begin{tabular}{|c|c|c|c|}
\hline Radiopharmaceutical & $\begin{array}{l}\text { Stage of } \\
\text { kidney failure } \\
\text { (CKD) }\end{array}$ & Dose recommendation & Other advice \\
\hline \multirow[t]{4}{*}[{}^{18}\mathrm{F}]{ fludeoxyglucose } & $1,2,3,4$ or 5 & $\begin{array}{l}\text { No adjustment in dose or } \\
\text { protocol is needed (Akers } \\
\text { et al. 2016; Kode et al. } \\
\text { 2017) }\end{array}$ & $\begin{array}{l}\text { No adjustment in image time (Akers } \\
\text { et al. 2016; Kode et al. 2017) }\end{array}$ \\
\hline & & $\begin{array}{l}\text { Dose adjustment should be } \\
\text { based on the optimized } \\
\text { radiation dose (Laffon } \\
\text { et al. 2008) }\end{array}$ & $\begin{array}{l}\text { The more severe the kidney failure, the } \\
\text { later the imaging should be, without } \\
\text { necessarily beginning the acquisition } \\
\text { beyond } 160 \text { min after injection (Laf- } \\
\text { fon et al. 2008) }\end{array}$ \\
\hline & & ND & $\begin{array}{l}\text { No large impact on assessment of scan } \\
\text { (Minamimoto et al. 2007) }\end{array}$ \\
\hline & 5 & ND & $\begin{array}{l}\text { The effect of elevated FDG uptake in } \\
\text { the background organs or blood } \\
\text { pool may influence interpretation of } \\
\text { the image in patients with CKD on } \\
\text { haemodialysis (Toriihara et al. 2015) }\end{array}$ \\
\hline
\end{tabular}

CKD, chronic kidney diseases; FDG, $\left[{ }^{18} \mathrm{~F}\right]$ fludeoxyglucose; ND, 'not determined'

\section{Quality of the observational studies}

We performed a methodological quality assessment of the included observational studies, namely five case-control studies (Table 4) and two cohort studies (Table 5). Our assessment yielded one study rated 'good' (14.3\%), one study rated 'fair' (14.3\%), and five studies rated 'poor' (71.4\%).

\section{Diagnostic radiopharmaceuticals and CKD}

Regarding diagnostic radiopharmaceuticals in patients with CKD, we found dose recommendations and advice only for the radiopharmaceutical FDG (Table 6). The following section summarises our findings for this radiopharmaceutical.

\section{$\left[{ }^{18}\right.$ F]fludeoxyglucose (FDG)}

A total of five studies reported the use of FDG in a total of 132 patients with CKD in several stages of CKD. Two of these studies recommended that no adjustment in dose or protocol is needed for patients with CKD. These studies based their recommendation on evidence that standardised uptake values in patients with CKD were comparable to those in patients with normal kidney function (Akers et al. 2016; Kode et al. 2017). One study suggested that a slight decrease in uptake in the brain and a slight increase in normal blood pool activity were caused by a higher FDG concentration in the blood and decreased uptake by tissues, and it concluded that these changes would not have a large impact on the assessment of the scan (Minamimoto et al. 2007). However, another study indicated that FDG uptake in background organs or blood pool might influence interpretation of the scan. In this case-control study, the standard uptake values (SUV) - normalised by body weight, as the control subjects had a greater body weight-in the gluteal muscles, subcutaneous fat, spleen, and right atrium were higher in patients on HD than in control subjects. The increased 


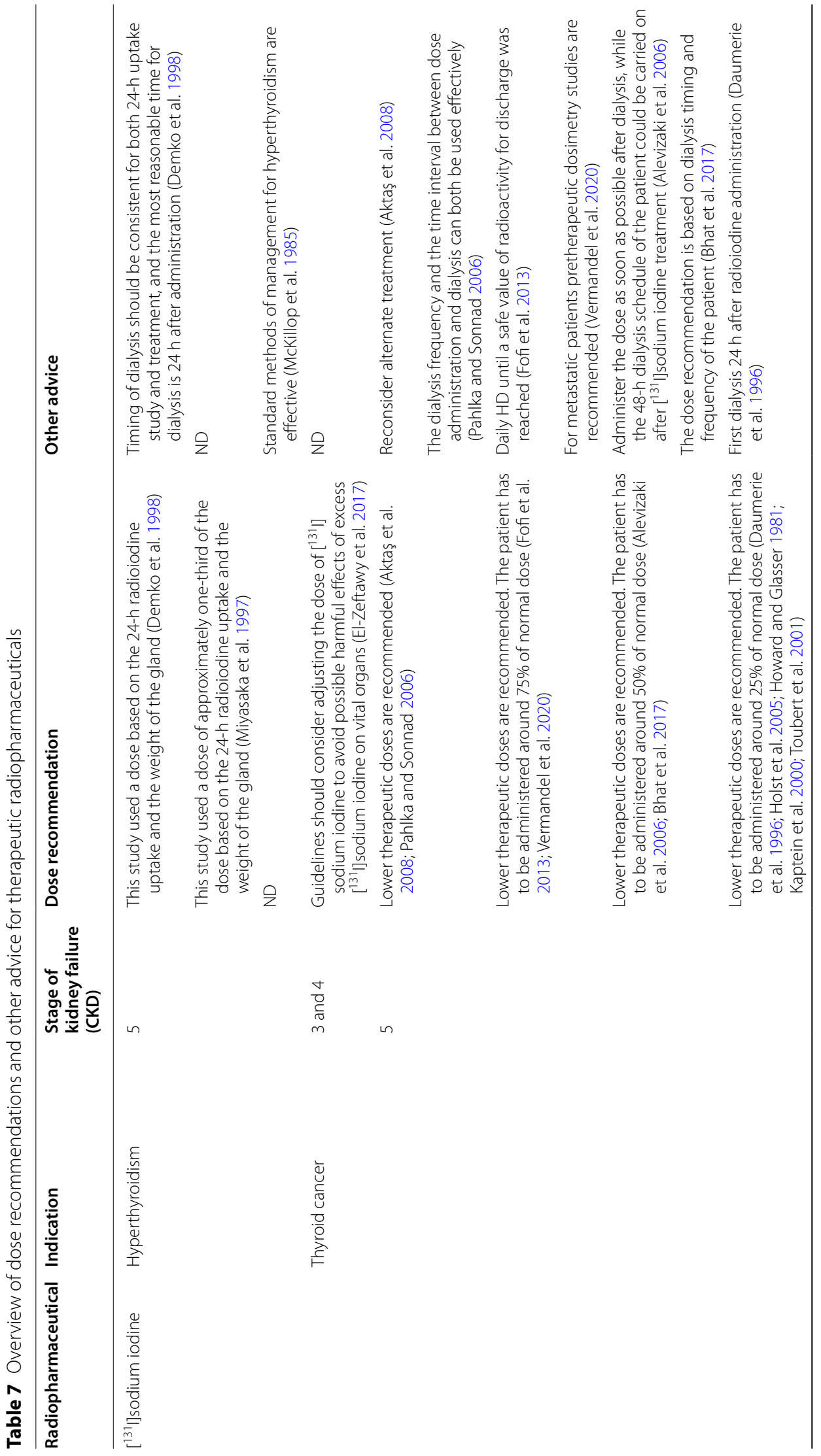


Schreuder et al. EJNMMI radiopharm. chem.

(2021) 6:27

Page 13 of 23

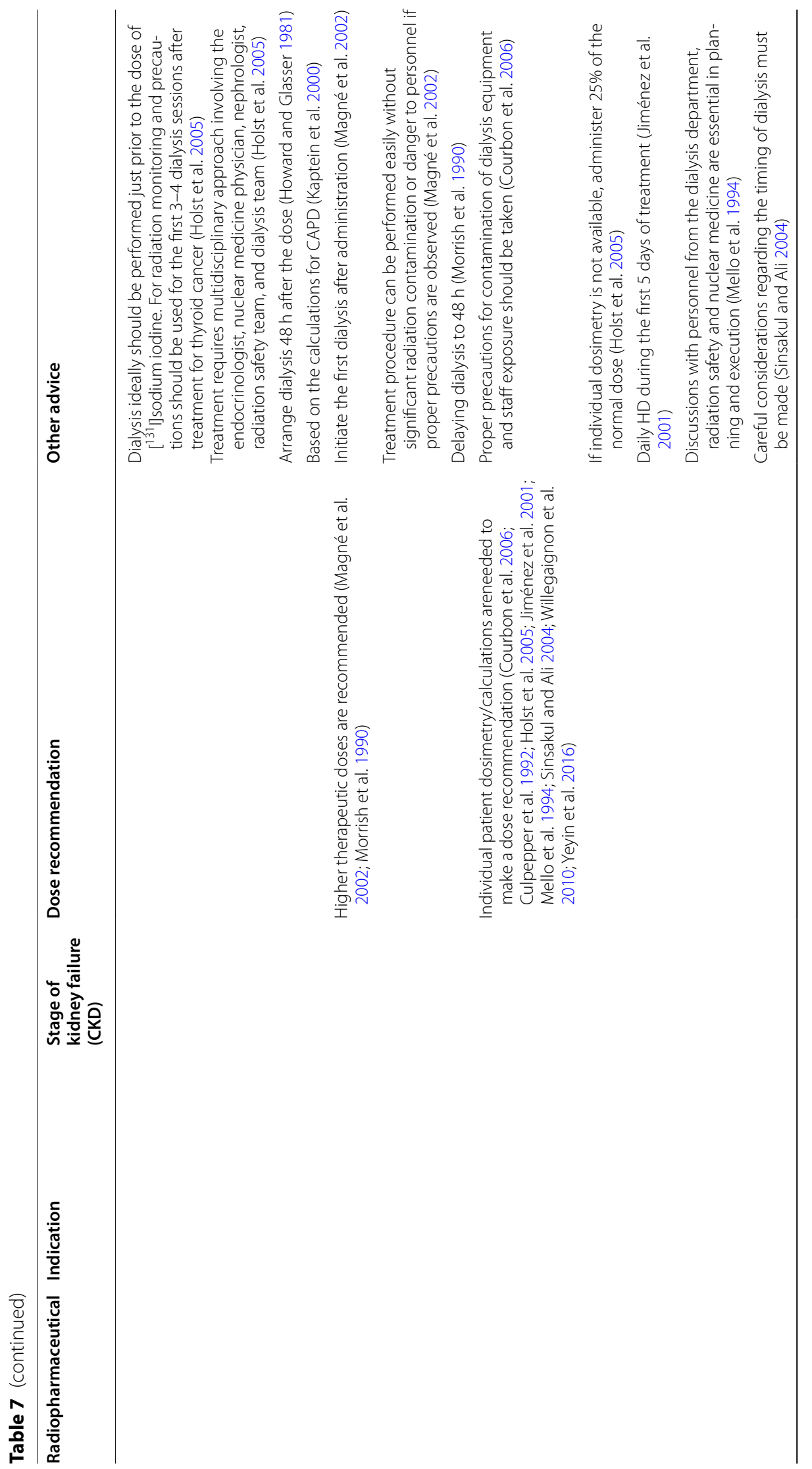




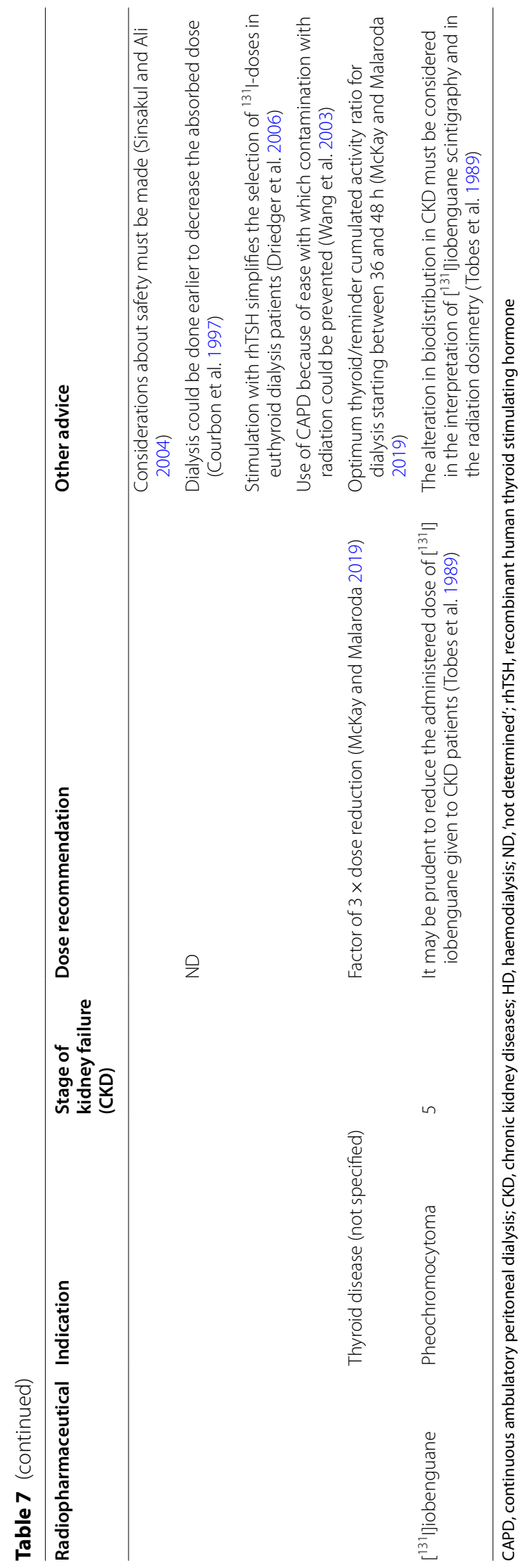


background uptake may influence quantitative measurements when the SUV of the background is used as a reference to assess tumour treatment response (Toriihara et al. 2015). A last study suggested, based on a theoretical assessment, to increase the time between radiopharmaceutical administration and imaging (Laffon et al. 2008).

\section{Therapeutic radiopharmaceuticals and CKD}

For the use of therapeutic radiopharmaceuticals in patients with CKD, we found dose recommendations and other advice for the treatment of hyperthyroidism and thyroid cancer with $\left[{ }^{131} \mathrm{I}\right]$ sodium iodine and for the treatment of pheochromocytoma with $\left[{ }^{131} \mathrm{I}\right]$ iobenguane (Table 7 ). The following sections summarise findings for these treatments.

\section{${ }^{131}$ I]sodium iodine for the treatment of hyperthyroidism}

Three case reports reported a total of three patients with CKD stage 5 on HD treated with $\left[{ }^{131} \mathrm{I}\right]$ sodium iodine for hyperthyroidism. Two of these studies calculated the dose of $\left[{ }^{131} \mathrm{I}\right]$ sodium iodine based on the 24-h radioiodine uptake and the weight of the thyroid gland (Demko et al. 1998; Miyasaka et al. 1997). In one of these two studies, HD was started after $24 \mathrm{~h}$. Approximately one-third of the calculated dose was administered, although the reason for reducing the dose in this way was not given (Miyasaka et al. 1997). The other study emphasised the importance of consistency in the timing of dialysis for both the iodine uptake assessment and the treatment, and it stated that the most reasonable time for dialysis is $24 \mathrm{~h}$ after administration (Demko et al. 1998). The third case-report study did not specify dose calculations, but it stated that standard management for hyperthyroidism is effective (McKillop et al. 1985). Of the three patients in these case reports, one developed hypothyroidism three months after treatment and later reached a euthyroid state (McKillop et al. 1985), and two patients remained in a euthyroid state (Demko et al. 1998; Miyasaka et al. 1997). Exact follow-up times were not given for these three patients.

\section{$\left[{ }^{131} I\right]$ sodium iodine for the treatment of thyroid cancer}

A total of 25 studies and case reports reported a total of 80 patients with CKD treated with $\left[{ }^{131} \mathrm{I}\right]$ sodium iodine for thyroid cancer. Of these studies, 24 (96.0\%) included patients with CKD stage 5 who were on dialysis. Only one study included patients with CKD stages 3 and 4 .

The latter study described the treatment of 27 patients with $\left.{ }^{131} \mathrm{I}\right]$ sodium iodine for ablation after thyroid cancer and reported a longer hospital stay and delayed renal clearance. It concluded that guidelines should consider adjusting the dose of $\left[{ }^{131} \mathrm{I}\right]$ sodium iodine in these patients to avoid increased radiation exposure (El-Zeftawy et al. 2017), but it did not specify the exact adjustment needed.

The dose recommendations differed in the studies with patients with CKD stage 5. Eleven studies $(45.8 \%)$ recommended a lower therapeutic dose, whereas two studies (8.3\%) recommended a higher therapeutic dose. Eight studies (33.3\%) indicated that the therapeutic dose should be calculated by individual patient dosimetry, and three studies (12.5\%) did not give dose recommendations but offered other advice. One study 
recommended that when it is not possible to calculate the therapeutic dose by individual patient dosimetry, a lower dose of $25 \%$ of the normal dose should be given (Holst et al. 2005). In the following paragraphs we describe the various dose recommendations for $\left.{ }^{[131} \mathrm{I}\right]$ sodium iodine treatment of thyroid cancer in patients with CKD stage 5.

Two studies recommended a lower therapeutic dose in patients with CKD stage 5 but did not quantify the optimal dose (Aktaş et al. 2008; Pahlka and Sonnad 2006). One of these studies based this recommended dose on a theoretical pharmacokinetic model that included both CAPD and HD with several regimes starting after $24 \mathrm{~h}$ or $48 \mathrm{~h}$ (Pahlka and Sonnad 2006). The other study-performed in 10 patients, with four patients on CAPD and six patients on HD starting after $24 \mathrm{~h}$-based their advice on higher and more persistent salivary gland, nasal, oral, and gastrointestinal uptake of $\left.{ }^{131} \mathrm{I}\right]$ sodium iodine in this group of patients. In this study, six patients experienced persistent xerostomia and one patient a transient epistaxis (Aktaş et al. 2008).

One study reduced the dose to $75 \%$ of the standard dose in two patients, based on literature also included in our review, and started HD $24 \mathrm{~h}$ after administration of the dose, followed by daily HD until a safe radiation dose rate was reached (Fofi et al. 2013). Another study recommended a 30\% reduction in dose for ablative or adjuvant therapies and a dose based on pretherapeutic dosimetry studies for metastatic patients. This study based these recommendations on absorbed dose in the bone marrow estimated from normalised measured whole-body activity (Vermandel et al. 2020).

Two studies recommended a dose reduction of up to $50 \%$ of the dose given to individuals without CKD. In the first study, in five patients, the dose was reduced by $40 \%$ up to $50 \%$, based on a previous case report and the researchers' own experience. Dialysis in the patients in this study was started $48 \mathrm{~h}$ after treatment. The patients did not experience discomfort during hospitalisation, and four were reported to be free of recurrence after a follow-up period of three years. For one patient, treatment was too recent for a valid follow-up (Alevizaki et al. 2006). The second study described the successful treatment of one patient with a $50 \%$ reduction in dose based on maintaining a comparable area under the curve of a plot of ${ }^{131}$ I-iodine activity as function of time (Bhat et al. 2017).

Five studies recommended a dose reduction to $25 \%$ of a standard dose, but the type and timing of dialysis varied by study. One of these studies successfully treated three patients with this dose based on a blood activity concentration-time curve (Daumerie et al. 1996). The second study successfully treated a patient with a lower dose based on the literature, although this patient did experience mild transient sialadenitis, which is a known adverse effect (GE Healthcare 2020). The authors provided a mathematical analysis showing that a patient on HD receiving $21-28 \%$ of a normal dose in combination with dialysis on days 2,3 , and 4 receives the same dose as a patient with normal kidney function (Holst et al. 2005). The third study used a dose of $25 \%$ of the normal dose based on the measurement of blood activity of a small tracing dose of $\left[{ }^{131} \mathrm{I}\right]$ sodium iodine in a patient with HD and reported successful ablation of tumour remnants (Howard and Glasser 1981). The fourth study successfully used $22 \%$ of a normal dose in a patient on CAPD (Toubert et al. 2001). The last of these five studies reduced the doses given to two CAPD patients to $18 \%-20 \%$ of the dose given to a patient with normal kidney function. There was no recurrence of thyroid cancer in either patient after treatment after a follow-up period of seven to eight years (Kaptein et al. 2000). 
Two studies recommended higher doses for dialysis patients than the doses used in patients with normal kidney function. Surprisingly, in one of these studies the authors suggested a dose of $125 \%$ of the normal dose, although they had treated a patient successfully with only $50 \%$ of a normal dose and started dialysis at $24 \mathrm{~h}$. They based their recommendation for the higher dose on the shorter half-life of ${ }^{131} \mathrm{I}$ calculated from dialysate samples $(2.7 \pm 0.8 \mathrm{~h})$ in comparison with the half-life of ${ }^{131} \mathrm{I}$ in a patient with normal kidney function (11.4 h) (Magné et al. 2002). The second study treated a patient with a higher dose than normal after an unsuccessful first treatment with a lower than normal dose (Morrish et al. 1990). The two studies disagreed on the timing of dialysis. One study recommended initiating dialysis right after $\left[{ }^{131} \mathrm{I}\right]$ sodium iodine administration (Magné et al. 2002), while the other study suggested delaying dialysis to $48 \mathrm{~h}$ after treatment to achieve a higher dose (Morrish et al. 1990). Another study indicated that the two studies recommending higher doses erred in their assumptions by not including a true effective half-life and not accounting for the almost complete lack of iodine clearance between dialysis sessions (Holst et al. 2005).

Eight studies did not give a dose recommendation but mentioned that the administered dose must be determined using individual patient dosimetry. Dosimetry prior to therapy aims to calculate the required dose by estimating the absorbable doses of radiation by internal organs and organs of interest based on the individual patient's iodine kinetics using a low dose of ${ }^{131}$ I (Courbon et al. 2006; Culpepper et al. 1992; Holst et al. 2005; Jiménez et al. 2001; Mello et al. 1994; Sinsakul and Ali 2004; Willegaignon et al. 2010; Yeyin et al. 2016). These studies indicated that it is difficult to make a standard recommendation because of the large range in effective half-life and other variables between patients, such as differences in the amount of thyroid remnant or residual kidney function (Holst et al. 2005) and differences in dialysis protocols (Courbon et al. 2006). Based on a mathematical analysis, one study-also discussed in the section about studies recommending a dose reduction to $25 \%$ of a standard dose-stated that when individual calculations are not available, $25 \%$ of the normal dose should be administered (Holst et al. 2005). In addition to the recommendation to use individual dosimetry calculations, some studies also offered safety advice, such as stating proper precautions against contamination of dialysis and staff exposure (Courbon et al. 2006; Sinsakul and Ali 2004). One study emphasised that discussions between personnel from the dialysis department, radiation safety, and nuclear medicine are essential in planning and executing the treatment with $\left[{ }^{131} \mathrm{I}\right]$ sodium iodine (Mello et al. 1994). Three studies did not make dose recommendations but offered other recommendations (Table 7). One study described a theoretical model of $\left[{ }^{131} \mathrm{I}\right]$ sodium iodine dosing in thyroid disease but did not specify which disease (McKay and Malaroda 2019).

\section{[131/]iobenguane}

One case report reported the use of $\left[{ }^{131} \mathrm{I}\right]$ iobenguane in a patient with kidney failure and compared the findings with data from two patients with mild to moderate loss of kidney function. This study did not make a specific dose recommendation, but it did indicate that the administered dose of $\left[{ }^{131} \mathrm{I}\right]$ iobenguane in patients with CKD should be reduced, given their reduced renal clearance of $\left[{ }^{131} \mathrm{I}\right]$ iobenguane (Tobes et al. 1989). 


\section{Discussion}

Based on a systematic review of the literature, which included 34 studies, consistent recommendations about radiopharmaceutical dosing in patients with CKD cannot be given. While studies do mention difficulties with the dosing of these medicines in patients with CKD, information is available for only a few radiopharmaceuticals, and recommendations are often contradictory.

Results for the diagnostic radiopharmaceutical FDG suggest that adjustment of the dose is not required, but some effect on the uptake of FDG must be considered in interpreting the scan. We found no results for other diagnostic radiopharmaceuticals. This finding was unexpected and may suggest that, even though altered biodistribution due to CKD may lead to a poor target-to-non-target ratio with diagnostic radiopharmaceuticals, no significant influence on image quality is apparent in daily practice. We hypothesise that for most diagnostic radiopharmaceuticals, CKD may be less important because inadequate tissue distribution and background clearance do not lead to clinically significant issues published, and technical and patient-related factors have a more important influence on scan quality. Further work is needed to investigate the effect of CKD on the biodistribution of diagnostical radiopharmaceuticals and the diagnostic outcome.

For the therapeutic radiopharmaceutical $\left[{ }^{131} \mathrm{I}\right]$ sodium iodine, the dosing recommendations are not in agreement. For treatment of thyroid cancer, most studies recommend dosing based on individual patient dosimetry calculations. Other studies recommend changing the dose, with advice varying from lowering the dose by $75 \%$ to increasing the dose. The variations in dose recommendations for $\left[{ }^{131} \mathrm{I}\right]$ sodium iodine might be explained by variability in individual patients and in used methods, including (a) differences in the amount of remnant thyroid tissue and tumour stage in general; (b) variation in residual kidney function; (c) variability in effective half-life; and (d) differences in method, timing, and frequency of dialysis treatment (Alevizaki et al. 2006; Bhat et al. 2017; Pahlka and Sonnad 2006; Sinsakul and Ali 2004; Meller et al. 2002).

Although the findings for therapeutic radiopharmaceuticals were limited, some studies indicated that dose adjustments in patients with CKD are important, and that altered biodistribution does affect therapeutic response and the risk of toxicity for non-target organs. A non-optimised dose in patients with CKD may lead to inadequate treatment (Aktaş et al. 2008), increased radiation exposure (El-Zeftawy et al. 2017), or an increased risk of adverse effects (for example, bone marrow toxicity, xerostomia, epistaxis, sialadenitis, or xerostomia from treatment with $\left[{ }^{131} \mathrm{I}\right]$ sodium iodine) (Aktaş et al. 2008; Alevizaki et al. 2006; Holst et al. 2005; Vermandel et al. 2020).

We found studies for only two therapeutic radiopharmaceuticals, and none providing dose recommendations for radiopharmaceuticals such as $\left[{ }^{177} \mathrm{Lu}\right] \mathrm{Lu}$-oxodotreotide or $\left[{ }^{90} \mathrm{Y}\right] \mathrm{Y}$-octreotide, even though CKD is described as a risk factor in ${ }^{177} \mathrm{Lu}$-somatostatin analogue treatment (Bodei et al. 2008b; Svensson et al. 2012), and the radiopharmaceutical's Summary of Product Characteristics warns that special consideration regarding the dose is required in these patients (Advanced Accelerator Applications 2020). In this regard, the European Medicines Agency has indicated that safety and efficacy studies often exclude patients with CKD (European Medicines Agency 2015). Therefore, we recommend including patients with CKD in studies, listing pharmacokinetic information regarding the influence of decreased kidney function, and providing specific dosing 
recommendations for therapeutic radiopharmaceuticals. With the introduction of new therapeutic radiopharmaceuticals, there is increased interest in patient-specific dosimetry. Although the practice of patient-specific dosimetry for therapeutic radiopharmaceuticals has been shown to vary across Europe (Sjögreen Gleisner et al. 2017), efforts are underway to optimise and standardise this practice (Stokke et al. 2017; Konijnenberg et al. 2021). Patient-specific dosimetry could play a role in predicting or verifying the dose of therapeutic radiopharmaceuticals in patients with CKD, and we suggest including CKD in future work on this topic.

Another finding is that most studies describe patients with CKD stage 5; only a few studies (8.8\%) include patients in other CKD stages. As the estimated prevalence of CKD is $11-13 \%$ in the general population, with the majority in CKD stage 3 and only $0.1 \%$ in CKD stage 5, one would expect more information to be available on patients in CKD stages 1-4 (Hill et al. 2016). It is difficult to explain these results. Possible explanations are that the effects of CKD stages $1-4$ on the results of the nuclear medicine examination are less pronounced than those of CKD stage 5 , that information on kidney function in patients in lower CKD stages is not available to the nuclear medicine staff, or that to date, kidney function has not been considered when planning for a patient. To develop a full picture of the dosing of radiopharmaceuticals in all CKD stages, future studies should include not only patients with CKD stage 5 , but also those in other stages.

Regarding patients in CKD stage 5 on renal treatment therapy, studies indicate that dialysis complicates the dosing of the radiopharmaceutical. Clearance of the radiopharmaceutical during dialysis may be altered or influenced by many aspects. First, characteristics of the substance such as molecular weight, solubility, binding to proteins, and volume of distribution are important to consider. In addition, dialysis-specific aspects such as the characteristics of the dialysis membrane, transmembrane pressure, dialysate flow rate, and timing and frequency of dialysis impact the clearance of the pharmaceutical (Velenosi and Urquhart 2014). These aspects complicate the treatment of patients with a therapeutic radiopharmaceutical and necessitate careful consideration of the timing and frequency of dialysis (Pahlka and Sonnad 2006; Sinsakul and Ali 2004). Other challenges for patients on renal treatment therapy receiving a therapeutic radiopharmaceutical include contamination of dialysis equipment and radiation exposure to staff. However, studies have shown that with proper precautions in planning and execution, the procedure can be performed safely (Courbon et al. 2006; Magné et al. 2002; Mello et al. 1994; Sinsakul and Ali 2004). A multidisciplinary approach, including the nuclear medicine physician, endocrinologist, nephrologist, radiation safety team, and dialysis team, is advised for treatment (Holst et al. 2005).

We believe our systematic review identifies an important gap in research for the dosing of radiopharmaceuticals in patients with CKD. The strength of our review is that we used a systematic approach and formulated a well-defined search string to identify available studies on radiopharmaceuticals and CKD. The researchers screened the included studies independently, which decreased the possibility of bias in this review.

A limitation of our review is that we only included published information on the dosing of radiopharmaceuticals in patients with CKD. Other data, such as data on file available from marketing authorisation holders or studies published in another language, may provide more insight into this subject. Although outside the scope of this study, an 
evaluation by an expert panel with diverse areas of expertise may also aid in compiling recommendations. Forming such an expert opinion is described for the safety evaluation of other drugs in combination with disease conditions and may well be a next step in clarifying the dosing of radiopharmaceuticals in patients with CKD (Weersink et al. 2018).

The quality of the included studies is not adequate for making reliable radiopharmaceutical dosing recommendations for patients with CKD. Most of the observational studies $(71.4 \%)$ were determined to be of 'poor' quality using the NOS. The study that was determined to be of 'good' quality included aspects such as a well-defined selection of both cohorts (patients with CKD and healthy volunteers) and an adequate follow-up (Minamimoto et al. 2007). For many included studies (79.4\%), a quality assessment using the NOS was not possible, because they were case reports and theoretical models. The quality of evidence is low, as many studies report only one case (such as dialysis patients) or consider only one factor (such as one radiopharmaceutical). It is apparent that more well-designed research needs to be done to include all radiopharmaceuticals and to include patients with CKD in various stages.

Uniform dose recommendations for radiopharmaceuticals based on kidney function are difficult to provide. Therefore, we recommend that additional research should be conducted to address this absence of information about radiopharmaceuticals and CKD and to provide appropriate dose recommendations for clinical practice. Evaluation of therapeutic radiopharmaceuticals in particular is important, because non-optimised dose for these radiopharmaceuticals may lead to inadequate treatment, increased radiation exposure, or an increased risk of adverse effects. With the introduction of new therapeutic radiopharmaceuticals, such as those based on alpha-emitting radionuclides, including patients with CKD may become even more important (Langbein et al. 2019).

\section{Conclusion}

This study has determined that information on the dosing of radiopharmaceuticals in patients with CKD is limited. While some studies do mention difficulties with dosing these medicines in these patients, information is available for only a few radiopharmaceuticals and for only some CKD stages. Moreover, recommendations are sometimes contradictory. Further research on the dosing of radiopharmaceuticals in patients with CKD is needed to determine whether specific dosing is required, especially for therapeutic radiopharmaceuticals where a non-optimised dose may lead to an increased risk of toxicity for non-targeted organs. Including patients with CKD in studies and providing specific information about dosing in these patients should be a priority for the radiopharmaceutical community.

Authors' contributions

All authors contributed to the study conception and design. Literature search, data collection and analysis were performed by I.d.R. and N.S. The first draft of the manuscript was written by N.S. and I.d.R. and all authors commented on previous versions of the manuscript. All authors read and approved the final manuscript.

Funding

No financial support was received for the conduct of this study or preparation of this manuscript.

Availability of data and material

The data that support the findings of this study are available from the corresponding author upon reasonable request. 


\section{Declarations}

Ethics approval and consent to participate

Not applicable.

\section{Consent for publication}

Not applicable.

\section{Competing interests}

N.S. is employed by GE Healthcare, however this work was part of his PhD trajectory at the University of Groningen. I.d.R., P.J., J.K., and E.V.P. have no conflicts of interest that are directly relevant to the content of this article.

\section{Author details}

${ }^{1}$ Groningen Research Institute of Pharmacy, Unit of PharmacoTherapy, Epidemiology and Economics, University of Groningen, Groningen, The Netherlands. ${ }^{2}$ GE Healthcare Radiopharmacy Zwolle, Zwolle, The Netherlands. ${ }^{3}$ Division of Pharmacoepidemiology and Clinical Pharmacology, Utrecht Institute for Pharmaceutical Sciences, Utrecht University, Utrecht, The Netherlands. ${ }^{4}$ Department of Nuclear Medicine, Isala Hospital, Zwolle, The Netherlands. ${ }^{5}$ Department of Clinical Pharmacy and Pharmacology, University Medical Center Groningen, University of Groningen, Groningen, The Netherlands. ${ }^{6}$ Netherlands Pharmacovigilance Centre Lareb, 's-Hertogenbosch, The Netherlands.

Received: 22 June 2021 Accepted: 9 August 2021

Published online: 21 August 2021

\section{References}

ACR-SNM-SPR practice guideline for the performance of cardiac scintigraphy. ACR practice guideline Oct. 2009. https:// www.snmmi.org/ClinicalPractice/content.aspx?!temNumber=6414. Accessed 13 Aug 2020.

Akers SR, Werner TJ, Rubello D, Alavi A, Cheng G. 18F-FDG uptake and clearance in patients with compromised renal function. Nucl Med Commun. 2016;37:825-32.

Aktaş A, Kavak K, Kocabaş B, Aras M, Tütüncü NB, Gençoğlu A. The biodistribution of radioiodine on posttherapy iodine-131 scans in thyroid cancer patients with chronic renal failure. Nucl Med Commun. 2008;29:943-8.

Alevizaki C, Molfetas M, Samartzis A, Vlassopoulou B, Vassilopoulos C, Rondogianni P, et al. lodine 131 treatment for differentiated thyroid carcinoma in patients with end stage renal failure: dosimetric, radiation safety, and practical considerations. Hormones. 2006;5:276-87.

Allisy A. From the curie to the becquerel. Metrologia. 1995;31:467-79.

Advanced Accelerator Applications. Lutathera - Summary of Product Characteristics (SPC). https://www.ema.europa.eu/ en/documents/product-information/lutathera-epar-product-information_en.pdf. Accessed 22 May 2020.

Balon HR, Brown TL, Goldsmith SJ, Silberstein EB, Krenning EP, Lang O, et al. The SNM practice guideline for somatostatin receptor scintigraphy 2.0. J Nucl Med Technol. 2011;39:317-24.

Bartel TB, Kuruva M, Gnanasegaran G, Beheshti M, Cohen EJ, Weissman AF, et al. SNMMI procedure standard for bone scintigraphy 4.0. J Nucl Med Technol. 2018;46:398-404.

Bhat M, Mozzor M, Chugh S, Buddharaju V, Schwarcz M, Valiquette G. Dosing of radioactive iodine in end-stage renal disease patient with thyroid cancer. Endocrinol Diabetes Metab Case Rep. 2017. https://doi.org/10.1530/EDM-17-0111.

Bodei L, Lam M, Chiesa C, Flux G, Brans B, Chiti A, et al. EANM procedure guideline for treatment of refractory metastatic bone pain. Eur J Nucl Med Mol Imaging. 2008a;35:1934-40.

Bodei L, Cremonesi M, Ferrari M, Pacifici M, Grana CM, Bartolomei M, et al. Long-term evaluation of renal toxicity after peptide receptor radionuclide therapy with 90Y-DOTATOC and 177Lu-DOTATATE: the role of associated risk factors. Eur J Nucl Med Mol Imaging. 2008b;35:1847-56.

Boellaard R, Delgado-Bolton R, Oyen WJ, Giammarile F, Tatsch K, Eschner W, et al. FDG PET/CT: EANM procedure guidelines for tumour imaging: version 2.0. Eur J Nucl Med Mol Imaging. 2015:42:328-54.

Bombardieri E, Ambrosini V, Aktolun C, Baum RP, Bishof-Delaloye A, Del Vecchio S, et al. 111ln-pentetreotide scintigraphy: procedure guidelines for tumour imaging. Eur J Nucl Med Mol Imaging. 2010;37:1441-8.

Centre for Reviews and Dissemination, University of York. PROSPERO, International prospective register of systematic reviews. https://www.crd.york.ac.uk/prospero/. Accessed 20 May 2019.

Chan P, Croasdale J. Survey of current therapeutic radiopharmaceuticals. In: Theobald T, editor. Sampson's textbook of radiopharmacy. 4th ed. London: Pharmaceutical Press; 2011. p. 303-23.

Coenen HH, Gee AD, Adam M, Antoni G, Cutler CS, Fujibayashi Y, et al. Open letter to journal editors. In: International consensus radiochemistry nomenclature guidelines. EJNMMI Radiopharm Chem. 2019.

Courbon F, Hoff M, Caselles O, Duthil P, Zedoud S, Berry I, et al. lodine-131 treatment of well differenciated thyroid carcinoma in patient on dialysis for chronic renal failure. Eur J Nucl Med. 1997;24:985.

Courbon F, Caselles O, Zerdoud S, Duthil P, Regis H, Berry I, et al. lodine-131 pharmacokinetics in patients on hemodialysis for end stage renal disease: clinical implications. Q J Nucl Med Mol Imaging. 2006;50:363-70.

Culpepper RM, Hirsch JI, Fratkin MJ. Clearance of 131I by hemodialysis. Clin Nephrol. 1992;38:110-4.

Dam HQ, Brandon DC, Grantham WV, Hilson AJ, Howarth DM, Maurer AH, et al. The SNMMI procedure standard/EANM practice guideline for gastrointestinal bleeding scintigraphy 2.0. J Nucl Med Technol. 2014;42:308-17.

Daumerie C, Vynckier S, Caussin J, Jadoul M, Squifflet JP, de Patoul N, et al. Radioiodine treatment of thyroid carcinoma in patients on maintenance hemodialysis. Thyroid. 1996;6:301-4.

Demko TM, Tulchinsky M, Miller KL, Cheung JY, Groff JA. Diagnosis and radioablation treatment of toxic multinodular goiter in a hemodialysis patient. Am J Kidney Dis. 1998;31:698-700. 
Djang DS, Janssen MJ, Bohnen N, Booij J, Henderson TA, Herholz K, et al. SNM practice guideline for dopamine transporter imaging with 1231-ioflupane SPECT 1.0. J Nucl Med. 2012;53:154-63.

Dreisbach AW, Lertora JJ. The effect of chronic renal failure on drug metabolism and transport. Expert Opin Drug Metab Toxicol. 2008;4:1065-74.

Driedger AA, Quirk S, McDonald TJ, Ledger S, Gray D, Wall W, et al. A pragmatic protocol for I-131 rhTSH-stimulated ablation therapy in patients with renal failure. Clin Nucl Med. 2006;31:454-7.

El-Zeftawy HA, Zekri JM, Farag K, Al-Saadi R, Sadiq BMB, Miliebari S. Radioiodine I-131 ablation therapy and impaired renal function: possible impact on guidelines. J Clin Oncol. 2017. https://doi.org/10.1200/JCO.2017.35.15_suppl.e17591.

European Medicines Agency: Guideline on the evaluation of the pharmacokinetics of medicinal products in patients with decreased renal function. London, European Medicines Agency, 2015. https://www.ema.europa.eu/en/docum ents/scientific-guideline/guideline-evaluation-pharmacokinetics-medicinal-products-patients-decreased-renalfunction_en.pdf. Accessed 28 May 2020.

Fahey F, Stabin M. Dose optimization in nuclear medicine. Semin Nucl Med. 2014;44:193-201.

Fofi C, Festuccia F, Barberi S, Apponi F, Chiacchiararelli L, Scopinaro F, et al. Hemodialysis in patients requiring 131/ treatment for thyroid carcinoma. Int J Artif Organs. 2013;36:439-43.

GE Healthcare BV. Theracap 131: summary of product characteristics (SPC). https://www.geneesmiddeleninformatiebank. nl/smpc/h57765_smpc.pdf. Accessed 14 Aug 2020.

Girndt M, Trocchi P, Scheidt-Nave C, Markau S, Stang A. The prevalence of renal failure. Results from the German health interview and examination survey for adults, 2008-2011 (DEGS1). Dtsch Arztebl Int. 2016;113:85-91.

Hill NR, Fatoba ST, Oke JL, Hirst JA, O'Callaghan CA, Lasserson DS, et al. Global prevalence of chronic kidney disease: a systematic review and meta-analysis. PLoS ONE. 2016;11:e0158765.

Holst JP, Burman KD, Atkins F, Umans JG, Jonklaas J. Radioiodine therapy for thyroid cancer and hyperthyroidism in patients with end-stage renal disease on hemodialysis. Thyroid. 2005;15:1321-31.

Hope TA, Abbott A, Colucci K, Bushnell DL, Gardner L, Graham WS, et al. NANETS/SNMMI procedure standard for somatostatin receptor-based peptide receptor radionuclide therapy with (177)Lu-DOTATATE. J Nucl Med. 2019;60:937-43.

Howard N, Glasser M. lodine 131 ablation therapy for a patient on maintenance haemodialysis. Br J Radiol. 1981;54:259-1285.

International Society of Nephrology. Chapter 1: Definition and classification of CKD. Kidney international supplements. 2013; 3:19-62. https://doi.org/10.1038/kisup.2012.64.

Jiménez RG, Moreno AS, Gonzalez EN, Simón FJL, Rodriguez JR, Jimenez JC, et al. lodine-131 treatment of thyroid papillary carcinoma in patients undergoing dialysis for chronic renal failure: a dosimetric method. Thyroid. 2001;11:1031-4.

Kaptein EM, Levenson H, Siegel ME, Gadallah M, Akmal M. Radioiodine dosimetry in patients with end-stage renal disease receiving continuous ambulatory peritoneal dialysis therapy. J Clin Endocrinol Metab. 2000;85:3058-64.

Kassis Al, Adelstein SJ. Radiobiologic principles in radionuclide therapy. J Nucl Med. 2005;46(Suppl 1):4S-12S.

Kode V, Karsch H, Osman MM, Muzaffar R. Impact of Renal Failure on F18-FDG PET/CT Scans. Front Oncol. 2017;7:155.

Konijnenberg M, Herrmann K, Kobe C, Verburg F, Hindorf C, Hustinx R, Lassmann M. EANM position paper on article 56 of the Council Directive 2013/59/Euratom (basic safety standards) for nuclear medicine therapy. Eur J Nucl Med Mol Imaging. 2021;48(1):67-72. https://doi.org/10.1007/s00259-020-05038-9.

Krens SD, Lassche G, Jansman FGA, Desar IME, Lankheet NAG, Burger DM, et al. Dose recommendations for anticancer drugs in patients with renal or hepatic impairment. Lancet Oncol. 2019;20:e200-7.

Laffon E, Cazeau AL, Monet A, de Clermont H, Fernandez P, Marthan R, et al. The effect of renal failure on 18F-FDG uptake: a theoretic assessment. J Nucl Med Technol. 2008;36:200-2.

Langbein T, Weber WA, Eiber M. Future of theranostics: an outlook on precision oncology in nuclear medicine. J Nucl Med. 2019;60(Suppl 2):13S-19S.

Lassmann M, Treves ST. EANM/SNMMI Paediatric Dosage Harmonization Working Group. Paediatric radiopharmaceutical administration: harmonization of the 2007 EANM paediatric dosage card (version 1.5.2008) and the 2010 North American consensus guidelines. Eur J Nucl Med Mol Imaging. 2014;41:1036-41.

Luster M, Clarke SE, Dietlein M, Lassmann M, Lind P, Oyen WJ, et al. Guidelines for radioiodine therapy of differentiated thyroid cancer. Eur J Nucl Med Mol Imaging. 2008;35:1941-59.

Magné N, Magné J, Bracco J, Bussière F. Disposition of radioiodine (131)l therapy for thyroid carcinoma in a patient with severely impaired renal function on chronic dialysis: a case report. Jpn J Clin Oncol. 2002;32:202-5.

Matzke GR, Frye RF. Drug administration in patients with renal insufficiency: minimising renal and extrarenal toxicity. Drug Saf. 1997;16:205-31.

McKay E, Malaroda A. Predicting the biodistribution of radioiodide in the setting of renal impairment and dialysis. Intern Med J. 2019:49:22.

McKillop JH, Leung AC, Wilson R. Successful management of Graves' disease in a patient undergoing regular dialysis therapy. Arch Intern Med. 1985;145:337-9.

Meller J, Sahlmann CO, Becker W. Nuclear medicine studies in the dialysis patient. Semin Dial. 2002;15:269-76.

Mello AM, Isaacs R, Petersen J, Kronenberger S, McDougall IR. Management of thyroid papillary carcinoma with radioiodine in a patient with end stage renal disease on hemodialysis. Clin Nucl Med. 1994;19:776-81.

Meredith R, Wessels B. Knox S. Risks to normal tissues from radionuclide therapy. Semin Nucl Med. 2008;38:347-57.

Minamimoto R, Takahashi N, Inoue T. FDG-PET of patients with suspected renal failure: standardized uptake values in normal tissues. Ann Nucl Med. 2007;21:217-22.

Miyasaka Y, Yoshimura M, Tabata S, Shozu A, Nishikawa M, Iwasaka T, et al. Successful treatment of a patient with Graves' disease on hemodialysis complicated by antithyroid drug-induced granulocytopenia and angina pectoris. Thyroid. 1997;7:621-4.

Moher D, et al. Preferred reporting items for systematic reviews and meta-analyses: the PRISMA statement. PLoS Med. 2009;6(7):e1000097. https://doi.org/10.1371/journal.pmed1000097.

Morrish DW, Filipow LJ, McEwan AJ, Schmidt R, Murland KR, von Westarp C, et al. 131I treatment of thyroid papillary carcinoma in a patient with renal failure. Cancer. 1990;66:2509-13. 
Munar MY, Singh H. Drug dosing adjustments in patients with chronic kidney disease. Am Fam Phys. 2007;75:1487-96. National Kidney Foundation, Inc. Kidney Disease. How to Classify CKD. https://www.kidney.org/professionals/exploreyour-knowledge/how-to-classify-ckd. Accessed 5 Jun 2019.

Nissenson AR, Pereira BJ, Collins AJ, Steinberg EP. Prevalence and characteristics of individuals with chronic kidney disease in a large health maintenance organization. Am J Kidney Dis. 2001;37:1177-83.

Ottawa Hospital Research Institute. Newcastle-Ottawa Scale. The Newcastle-Ottawa Scale (NOS) for assessing the quality of nonrandomised studies in meta-analyses. www.ohri.ca/programs/clinical_epidemiology/oxford.asp. Accessed 5 Jun 2019.

Pahlka RB, Sonnad JR. The effects of dialysis on 1311 kinetics and dosimetry in thyroid cancer patients-a pharmacokinetic model. Health Phys. 2006;91:227-37.

Pickett R. Radiopharmacokinetics. In: Theobald T, editor. Sampson's textbook of radiopharmacy. 4th ed. London: Pharmaceutical Press; 2011. p. 219-47.

Poeppel TD, Handkiewicz-Junak D, Andreeff M, Becherer A, Bockisch A, Fricke E, et al. EANM guideline for radionuclide therapy with radium-223 of metastatic castration-resistant prostate cancer. Eur J Nucl Med Mol Imaging. 2018:45:824-45.

Saracyn M, Bilski M, Kaminski G, Niemczyk S. Can radioiodine be administered effectively and safely to a patient with severe chronic kidney disease? Clin Endocrinol (oxf). 2014;81:169-74.

Silberstein EB, Alavi A, Balon HR, Clarke SE, Divgi C, Gelfand MJ, et al. The SNMMI practice guideline for therapy of thyroid disease with 131। 3.0. J Nucl Med. 2012;53:1633-51.

Silberstein EB, Buscombe JR, McEwans A, Taylor AT. Society of nuclear medicine procedure quideline for palliative treatment of painful bone metastases. In: Society of nuclear medicine procedure guidelines manual. 2003. p. 145-153.

Singh M, Kaur J, Singh S, Thumburu K, Jaiswal N et al. Comparison of Newcastle Ottawa scale (NOS) and Agency for Health Research and Quality (AHRQ) as risk of bias assessment tools for cohort studies. Filtering the information overload for better decisions. Abstracts of the 23rd Cochrane Colloquium. . John Wiley and Sons, Vienna, Austria. 2015.

Sinsakul M, Ali A. Radioactive 131l use in end-stage renal disease: nightmare or nuisance? Semin Dial. 2004;17:53-6.

Sjögreen Gleisner K, Spezi E, Solny P, Gabina PM, Cicone F, Stokke C, et al. Variations in the practice of molecular radiotherapy and implementation of dosimetry: results from a European survey. EJNMMI Phys. 2017:4:28.

Smith BT. Radioactive drugs in medicine: radiopharmaceuticals. In: Smith BT, Weatherman KD, editors. Diagnostic imaging for pharmacists. 1st ed. Washington, DC: American Pharmacists Association; 2012. p. 2-8.

Stokke C, Gabiña PM, Solný P, Cicone F, Sandström M, Gleisner KS, Chiesa C, Spezi E, Paphiti M, Konijnenberg M, Aldridge M, Tipping J, Wissmeyer M, Brans B, Bacher K, Kobe C, Flux G. Dosimetry-based treatment planning for molecular radiotherapy: a summary of the 2017 report from the Internal Dosimetry Task Force. EJNMMI Phys. 2017;4(1):27. https://doi.org/10.1186/s40658-017-0194-3.

Svensson J, Hermann R, Larsson M, Forssell-Aronsson E, Wängberg B, AhIman H, et al. Impairment in renal function predicts higher absorbed doses to the kidneys in peptide receptor radionuclide therapy. Eur J Nucl Med Mol Imaging 2012:39:5307.

Tobes MC, Fig LM, Carey J, Geatti O, Sisson JC, Shapiro B. Alterations of iodine-131 MIBG biodistribution in an anephric patient: Comparison to normal and impaired renal function. J Nucl Med. 1989;30:1476-82.

Toriihara A, Kitazume Y, Nishida H, Kubota K, Nakadate M, Tateishi U. Comparison of FDG-PET/CT images between chronic renal failure patients on hemodialysis and controls. Am J Nucl Med Mol Imaging. 2015;5:204-11.

Toubert ME, Michel C, Metivier F, Peker MC, Rain JD. lodine-131 ablation therapy for a patient receiving peritoneal dialysis. Clin Nucl Med. 2001;26:302-5.

Van den Wyngaert T, Strobel K, Kampen WU, Kuwert T, van der Bruggen W, Mohan HK, et al. The EANM practice guidelines for bone scintigraphy. Eur J Nucl Med Mol Imaging. 2016;43:1723-38.

Velenosi TJ, Urquhart BL. Pharmacokinetic considerations in chronic kidney disease and patients requiring dialysis. Expert Opin Drug Metab Toxicol. 2014;10:1131-43.

Vermandel M, Debruyne P, Beron A, Devos L, Talbot A, Legrand JF, et al. Management of patients with renal failure undergoing dialysis during (131)I therapy for thyroid cancer. J Nucl Med. 2020;61:1161-70.

Wang TH, Lee CH, Tseng LM, Liu RH. The management of well-differentiated thyroid cancer with end-stage renal disease. Endocrine. 2003;21:227-31.

Weersink RA, Bouma M, Burger DM, Drenth JPH, Harkes-Idzinga SF, Hunfeld NGM, et al. Evidence-based recommendations to improve the safe use of drugs in patients with liver cirrhosis. Drug Saf. 2018;41:603-13.

WHO Collaborating Centre for Drug Statistics Methodology. ATC/DDD Index 2019. https://www.whocc.no/atc_ddd_ index/. Accessed 14 Jun 2019.

Willegaignon J, Ribeiro VP, Sapienza M, Ono C, Watanabe T, Buchpiguel C. Is it necessary to reduce the radioiodine dose in patients with thyroid cancer and renal failure? Arq Bras Endocrinol Metabol. 2010;54:413-8.

Yeyin N, Cavdar I, Uslu L, Abuqbeitah M, Demir M. Effects of hemodialysis on iodine-131 biokinetics in thyroid carcinoma patients with end-stage chronic renal failure. Nucl Med Commun. 2016;37:283-7.

Zaknun JJ, Bodei L, Mueller-Brand J, Baum RP, Pavel ME, Hörsch D, et al. The joint IAEA, EANM, and SNMMI practical guidance on peptide receptor radionuclide therapy (PRRNT) in neuroendocrine tumours. Eur J Nucl Med Mol Imaging. 2013:40:800-16.

\section{Publisher's Note}

Springer Nature remains neutral with regard to jurisdictional claims in published maps and institutional affiliations. 